\section{Genetic parameters and selection of sugarcane in early selection stages for resistance to sugarcane borer Diatraea saccharalis}

\section{Adriano Cirino Tomaz ${ }^{1 *}$, Cleiton Antonio Wartha ${ }^{2}$, Marcos Deon Vilela de Resende ${ }^{3}$, Bruno Portela Brasileiro ${ }^{4}$, Luiz Alexandre Peternelli ${ }^{2}$ and Márcio Henrique Pereira Barbosa ${ }^{2}$}

\begin{abstract}
A T1 (sugarcane population originating from true seeds) and T2 (first sugarcane clonal stage) population were used to estimate genetic parameters and compare selection strategies for Diatraea saccharalis (Lepidoptera: Crambidae) resistance in sugarcane. In the T1 stage, heritability at the family mean level $\left(h^{2}=0.77\right)$ was higher than individual genotype heritability $\left(h^{2}=0.16\right)$, and the additive genetic effect was more important for sugarcane borer resistance than non-additive effects. In addition, there was high genotypic variance among and within full-sib families. In the T2 population, genotypic variance was high, and heritability at the clone mean level was moderate $\left(h^{2}=0.61\right)$. We can conclude that family experiments enable selection of more promising families and parents for borer resistance. However, due to high genotypic variance within families, family selection at the T1 stage must be followed by clone selection at the $T 2$ stage.
\end{abstract}

Keywords: Saccharum spp., Diatraea saccharalis, full-sib families.

\section{INTRODUCTION}

The sugarcane stalk borer Diatraea saccharalis Fab. (Lepidoptera: Crambidae) is one of the main sugarcane pests in Brazil (Dinardo-Miranda et al. 2012). This pest is controlled primarily by use of the parasitoid Cotesia flavipes (Hymenoptera: Braconidae) and chemical insecticides. The use of sugarcane varieties resistant to the borer could be an important tool for Integrated Management, reducing the costs associated with Cotesia releases and insecticide spraying. There are some efforts to develop sugarcane varieties resistant to $D$. saccharalis through biotechnology, especially by inserting $B t$ genes, derived from Bacillus thuringiensis bacteria, into commercial varieties (Cristofoletti et al. 2018). However, there is a possibility of rapid evolution of sugarcane borer resistance to Bt proteins with large-scale field use (Girón-Pérez et al. 2014).

Previous studies have demonstrated that some sugarcane genotypes in Brazil have genes that confer some degree of resistance to $D$. saccharalis. This resistance is due to the presence of some leaf component that causes higher mortality of early-stage larvae, some barrier on the stalk surface that hinders or delays larvae penetration within the stalks, or some trait within the stalks that reduces larval feeding and/or affects larval performance (Dinardo-Miranda et al. 2012, Tomaz et al. 2017, Pimentel et al. 2017). Resistance genes are likely
Crop Breeding and Applied Biotechnology 19: 208-216, 2019 Brazilian Society of Plant Breeding. Printed in Brazil http://dx.doi.org/10.1590/198470332019v19n2a29

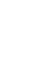


to provide more durable protection than that conferred by Bt genes. Thus, it is possible to increase the resistance of sugarcane varieties to borer by selecting and recombining genotypes with resistance traits. The registration of sugarcane genotypes resistant to borer through common breeding efforts in the United States reinforces this possibility (White et al. 1993, White et al. 1998, White et al. 2011).

Sugarcane breeding programs usually start by evaluating large numbers of seedlings derived from true seed, obtained from programmed cross-breeding. The first selection stage (T1 stage) is planted with true seed, and subsequent stages are planted using vegetative propagation. T1 stage is considered the most important stage of sugarcane breeding when the first genotypes are selected (Peternelli et al. 2017). Selection for borer resistance at the T1 stage could increase the frequency of favorable alleles, increasing the resistance of the population for the following selection stages. Individual (mass) selection is inefficient at this stage for traits with low heritability, such as borer resistance, due to the lack of replication for individual genotypes (Santana et al. 2017). Family selection is particularly useful for traits with low heritability because, unlike clones, families can be evaluated using replicated plots and across years and sites, thereby improving estimates of family means (Kimbeng and Cox 2003). Family selection, when followed by individual clone selection, is superior in terms of genetic gain than either family or individual clone selection alone (Brasileiro et al. 2016). The availability of family data makes it possible to estimate the breeding value of parents using the Best Linear Unbiased Predictors (BLUP), and it enables planning for better cross combinations (Santana et al. 2017). The BLUP allows data from a diverse range of mating designs and parent, family, and individual data to be combined into a single breeding value for each trait and genotype (Kimbeng and Cox 2003, Barbosa et al. 2004).

Family experiments can also be used to study the importance of additive and non-additive genetic effects. This information is beneficial for designing the best breeding strategies. When the non-additive genetic effects are important for a trait, there is the possibility of increasing genetic gain by exploiting heterosis through selection of crosses with high specific combining ability (SCA). When there is a predominance of additive genetic effects, genotypes can be selected based on their per se performance or their general combining ability (GCA) (Bastos et al. 2003). White et al. (2001) reported that additive genetic variance is more important than dominance variance in determining resistance of sugarcane to $D$. saccharalis. However, for sugarcane resistance to African borer, both additive and non-additive genetic effects may be present (Zhou 2015).

Family experiments have been used to study genetic inheritance and selection strategies and to identify superior families and parents for sugarcane resistance to African sugarcane borer Eldanna saccharina (Lepidoptera: Pyralidae) (Zhou 2015, 2016, Zhou and Mokwele 2016). In Brazil, family studies have mainly focused on selecting families and parents for yield traits, especially tons of stalk per hectare (Barbosa et al. 2004, Barbosa et al. 2005). However, no family studies have been conducted to determine the genetics of resistance to $D$. saccharalis in sugarcane. Such studies could enable determination of selection strategies and identification of promising clones, families, and parents for D. saccharalis resistance.

In this study, a T1 (seedlings originating from true seed) and a T2 (first clonal selection stage) population were used to estimate genetic parameters, to compare selection strategies, and to identify superior parents, families, and clones for borer resistance. The purpose of using the T1 stage was to estimate heritability on a family mean basis and individually, genotypic variance among families, and additive and dominance genetic effects; to compare individual, family, or parent selection; and to identify promising parents and families for resistance to borer. The T2 stage aimed to estimate heritability for clone means and genotypic variance among clones, to assess the efficiency of family selection at the $\mathrm{T} 1$ stage, and to identify clones with superior borer resistance.

\section{MATERIAL AND METHODS}

\section{Selection of sugarcane for borer resistance at the seedling stage (T1)}

\section{Plant material and experimental design}

Seedlings were germinated in March 2014 from true seeds in a glasshouse at the "Centro de pesquisa e melhoramento da cana-de-açúcar" (CECA), a sugarcane research station in the municipality of Oratórios, Minas Gerais, Brazil. This station belongs to the sugarcane breeding program of UFV (Universidade Federal de Viçosa), in partnership with the 
Table 1. Families and parents used in the experiment for evaluating inheritance of sugarcane borer resistance and selection for borer resistance at the seedling stage

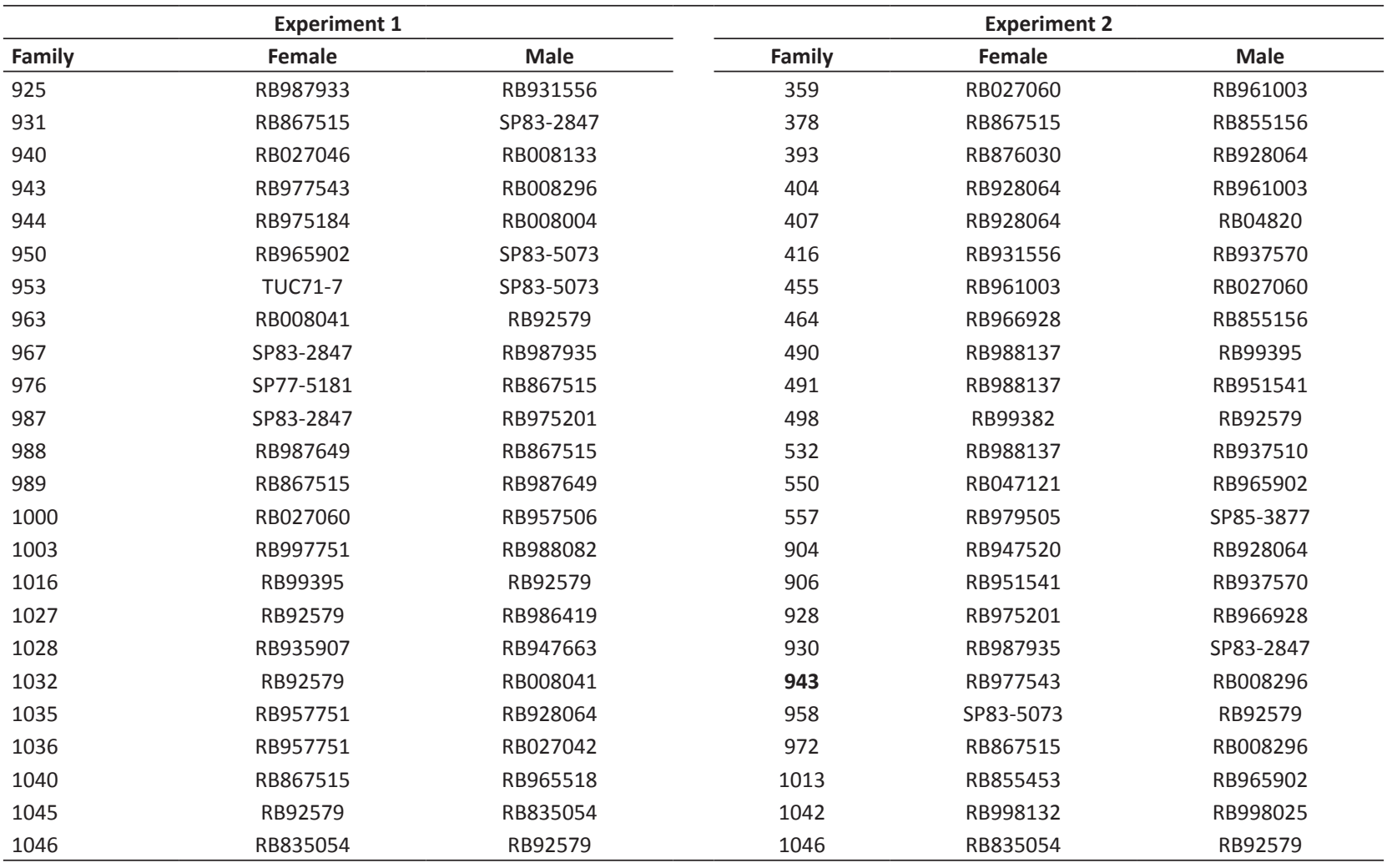

The control families are highlighted in bold

Inter-University Network for Development of the Sugarcane Industry (RIDESA) (Barbosa et al. 2012). The seedlings were then transplanted to a field area with a historically high natural borer population in a partner sugarcane mill in the muncipality of Iturama, Minas Gerais, in December 2014. To maintain high borer infestation, no chemical or biological control of borer was applied in the area during the experiment.

The sugarcane families were divided into two experiments in the same area, containing 24 families each. Two families (943 and 1046) were planted in both experiments to be used as controls. The plots were composed of a single row (14.5 $\mathrm{m})$, containing 25 plants of each family. The spacing between rows was $1.5 \mathrm{~m}$, and the spacing between plants within a row was $0.6 \mathrm{~m}$. The plants were fertilized with $400 \mathrm{~kg} \mathrm{ha}^{-1}$ of 04-30-16 (N-P-K). The experiment was conducted in a randomized block design with 46 full-sib families (Table 1 ) and four replicates per family.

\section{Data collection}

Borer damage was assessed in July 2015. Ten plants per plot were randomly selected for this assessment. Two stalks per plant (individuals) were harvested, and the number of total internodes and bored internodes per stalk were recorded to calculate the percentage of bored internodes per plant. Estimation of the infestation index per stool was calculated by using the mean of both stalks. Each family was represented by nearly 40 individuals (4 plots $\times 10$ individuals/plot). However, in some plots, fewer plants were assessed, due to the death of some seedlings.

\section{Data analysis}

The data for the infestation index were analyzed using the Selegen-REML/BLUP software (statistical system and computerized genetic selection by linear mixed models). The data of the two experiments were analyzed together by mixed models (Resende 2016), with the means adjusted by the means of the repeated checks. The first model was used 
to estimate genetic parameters for family selection and the following formula was used:

$$
y=X_{b}+Z_{f}+W_{j}+\varepsilon
$$

where $y$ is the vector of data, $X_{b}$ is the vector of fixed effect of blocks, $Z_{f}$ is the vector of random effect of families, $W_{j}$ is the vector of random effect of plots, and $\varepsilon$ is the vector of residual or random error.

Broad-sense heritability was estimated on a family mean basis using the following formula:

$$
h_{f m}^{2}=\sigma_{f}^{2} /\left(\sigma_{f}^{2}+\sigma_{b}^{2} / r+\sigma^{2} / g r\right)
$$

where $\sigma_{f}^{2}$ is the genotypic variance among full-sib progenies, equivalent to $1 / 2$ of genetic additive variance $+1 / 4$ of genetic dominance variance and ignoring epistasis; $\sigma_{b}^{2}$ is the variance among blocks; $\sigma^{2}$ is the residual variance; $r$ is the number of blocks; and $g$ is the number of families. The accuracy of selecting by family means was calculated as $A c=\sqrt{h_{f m}}$ where $h_{f m}$ is the heritability at family means level.

The second model that follows was used to estimate genetic parameters for parent and individual selection:

$$
y=X_{r}+Z_{a}+W_{j}+T_{d}+\varepsilon
$$

where $y$ is the vector of data, $X_{r}$ is the fixed effect of blocks, $Z_{a}$ is the vector of random additive genetic effects, $W_{j}$ is the vector of random plot effects, $T_{d}$ is the vector of random dominance genetic effects (for full-sib progenies), and $\varepsilon$ is the vector of residual or random error, ignoring the variance of epistatic effects. The capital letters are the incidence matrices for such effects.

The following formulas were used to calculate narrow-sense and broad-sense heritabilities:

1) $h_{a}^{2}=\sigma_{a}^{2} / \sigma_{p}^{2}$

2) $h_{g}^{2}=\sigma_{a}^{2}+\sigma_{d}^{2} / \sigma_{p}^{2}$

where $\sigma_{a}^{2}$ is the additive genetic variance, $\sigma_{d}^{2}$ is the dominance effect, and $\sigma_{p}^{2}$ is the phenotypic variance.

The variance components were estimated by the REML (restricted maximum likelihood) procedure, and the significance of the effects was tested using deviance analysis by the likelihood ratio test (LRT). The genotypic values of families and additive genetic effects of the parents were estimated using the best linear unbiased predictors (BLUP).

\section{Selection of sugarcane for borer resistance at the first clonal stage (T2)}

\section{Plant material and experimental design}

In April 2016, sugarcane breeders of RIDESA, following the parameters of routine mass selection, selected superior individuals from the $\mathrm{T} 1$ population. To compose the first clonal stage (T2), 32 individuals from the three most resistant families and 32 individuals from the three most susceptible families were selected to compose a resistant and a susceptible group, respectively. The T2 population was composed of 64 individuals, which were planted in the field of the research station (CEPET) of UFV (Federal University of Viçosa), in the municipality of Capinópolis, Minas Gerais.

Each plot was made up of a single row $(1 \mathrm{~m})$ and spacing between plots was $1.0 \mathrm{~m}$. The plants were fertilized with 400 $\mathrm{kg} \mathrm{ha}^{-1}$ of 04-30-16 (N-P-K). This experiment was conducted in a randomized block design with five replicates per clone.

\section{Data collection}

Sugarcane damage was assessed in July 2017. Four stalks per plot were harvested and the number of total internodes and bored internodes per stalk were recorded to calculate the percentage of bored internodes per plot.

\section{Data analysis}

The data of the infestation index were analyzed using the Selegen-REML/BLUP (Statistical system and computed genetic selection using linear mixed models) software (Resende 2016). The following model was used to estimate genetic parameters for clonal selection: 


$$
y=Z_{f}+W_{b}+S_{c}+\varepsilon
$$

where $y$ is the vector of data, $Z_{f}$ is the vector of full-sib families (random), $W_{b}$ is the vector of the random effects of blocks, $S_{c}$ is the vector of clones within families (random), and $\varepsilon$ is the vector of residual or random error. The capital letters are the incidence matrices for the effects.

The variance components were estimated by the REML (restricted maximum likelihood) procedure, and the significance of the effects were tested by using deviance analysis. The genotypic values of clones were estimated using best linear unbiased predictors (BLUP). The heritability at the clone means level was calculated by the following formula:

$$
h_{c}^{2}=\sigma_{f}^{2}+\sigma_{c / f}^{2} /\left(\sigma_{f}^{2}+\sigma_{c / f}^{2}+\sigma^{2} / r\right)
$$

where $\sigma_{f}^{2}$ is the genotypic variance among full-sib progenies, equivalent to $1 / 2$ of genetic additive variance $+1 / 4$ of genetic dominance variance and ignoring epistasis; $\alpha_{c / f}^{2}$ is the genetic variance among clones within families, equivalent to $1 / 2$ of genetic additive variance $+3 / 4$ of genetic dominance variance; $\alpha^{2}$ is the residual variance and $r$ is the number of blocks.

\section{RESULTS AND DISCUSSION}

\section{Selection of sugarcane for borer resistance at the seedling stage (T1)}

The genotypic variance $\left(\sigma_{g}^{2}=15.52\right)$ for family effect was significant $(P<0.001)$, indicating that there is difference among family means. The broad-sense heritability at the family mean level was high $\left(h^{2}=0.77\right)$, as well as the accuracy of family selection ( $A c=0.88$ ) (Table 2 ). This heritability was close to that found for the infestation index of $D$. saccharalis $\left(h_{f m}^{2}=0.76\right)$ and African borer $E$. saccharina $\left(h^{2}=0.51-0.56\right)$ (White et al. 2001, Zhou 2015, 2016). In contrast, the individual heritability was low $\left(h_{g}^{2}=0.16\right)$ (Table 2$)$. Therefore, selection of individuals within a family or individual selection is less effective than family selection for borer resistance at the T1 stage. Similar results were found for sugarcane resistance to $D$. saccharalis and African sugarcane borer (White et al. 2001, Zhou and Mokwele 2016).

The genotypic values for family means $(u+g)$ ranged from 18.41 to $30.41 \%$ of bored internodes, confirming the difference among families (Table 3 ). In addition, the predicted genetic gain from selecting the 10 most resistant families (selection intensity 20\%) was $-17.5 \%$. Thus, selecting sugarcane families at the $\mathrm{T} 1$ stage could enable the formation of breeding populations that are more resistant to borer. The families RB027060 × RB957506, RB876030 × RB928064, RB988137 × RB951541, RB966928 × RB855156, and RB987649 $\times$ RB867515 were the families most resistant to borer. The accuracy of predicting genotypic values for family means ranged from 0.73 to 0.86 , depending on the number of individuals per family (Table 3 ). Therefore, the use of at least 40 individuals per family is recommended to obtain satisfactory accuracies ( $>75 \%$ ).

The variance due to the additive genetic effect was highly significant $\left(\sigma_{a}^{2}=37.03\right)(P<0.001)$ while the dominance variance on non-additive effects was not

Table 2. Variance components (REML), means, and heritabilities for sugarcane borer resistance at the seedling stage (T1) and first

\begin{tabular}{|c|c|c|c|}
\hline \multirow{2}{*}{$\begin{array}{l}\text { Variance } \\
\text { Components }\end{array}$} & \multicolumn{2}{|c|}{ T1 stage } & \multirow{2}{*}{$\begin{array}{c}\text { T2 stage } \\
\begin{array}{c}\text { Clone } \\
\text { selection }\end{array}\end{array}$} \\
\hline & Family selection & Parent selection & \\
\hline$\sigma_{g}^{2}$ & $15.52^{* *}$ & & \\
\hline$\sigma_{a}^{2}$ & & $37.03 * *$ & \\
\hline$\sigma_{d}^{2}$ & & 0.35 & \\
\hline$\sigma_{f}^{2}$ & & & 1.47 \\
\hline$\sigma_{c / f}^{2}$ & & & $9.13 * *$ \\
\hline$\sigma^{2}$ & 211.47 & 192.92 & 34.17 \\
\hline$\sigma_{p}^{2}$ & 243.79 & 245.64 & 45.64 \\
\hline $\mathrm{h}_{f m}^{2}$ & 0.77 & & \\
\hline$h_{a}^{2}$ & & $0.15 \pm 0.036$ & \\
\hline$h_{g}^{2}$ & & 0.16 & \\
\hline$c_{d}^{2}$ & & 0.01 & \\
\hline$h_{f}^{2}$ & & & 0.03 \\
\hline$h_{c}^{2}$ & & & 0.61 \\
\hline$A c_{f m}$ & 0.88 & & \\
\hline $\mathrm{Ac}_{\mathrm{gm}}$ & & & 0.78 \\
\hline Mean & 24.36 & 24.28 & 11.82 \\
\hline
\end{tabular}
clonal stage (T2)

$\sigma_{g}^{2}=$ genotypic variance among full-sib families at T1 stage, $\sigma_{a}^{2}=$ additive genetic variance at $\mathrm{T} 1$ stage, $\sigma_{d}^{2}=$ dominance genetic variance or specific combining ability at $\mathrm{T} 1$ stage, $\sigma_{f}^{2}=$ genotypic variance among full-sib progenies at T2 stage, $\sigma_{c / f}^{2}=$ genetic variance among clones within families at $T 2$ stage, $\sigma^{2}=$ residual variance or error (random), $\sigma^{2}=$ phenotypic variance, $\mathrm{h}^{2}=$ broad-sense heritability for family means at T1 stage, $h_{a}^{2}=$ narrow-sense heritability at T1 stage, $h_{q}^{2}=$ individual broadsense heritability at T1 stage, $c_{d}^{2}=$ determining coefficient of specific combining ability at T1 stage, $h_{f}^{2}=$ broad-sense heritability for family means at T2 stage, $h_{c}^{2}=$ broad-sense heritability for clone mean at T2 stage; $\mathrm{Ac}_{\mathrm{fm}}=$ accuracy for selection by family means at $\mathrm{T} 1$ stage and $A c_{g m}=$ accuracy of clone selection at $\mathrm{T} 2$ stage. 
Genetic parameters and selection of sugarcane in early selection stages for resistance to sugarcane borer Diatraea saccharalis

Table 3. Genotypic values (BLUP) for infestation index by borer (IIB) in the seedling stage (T1)

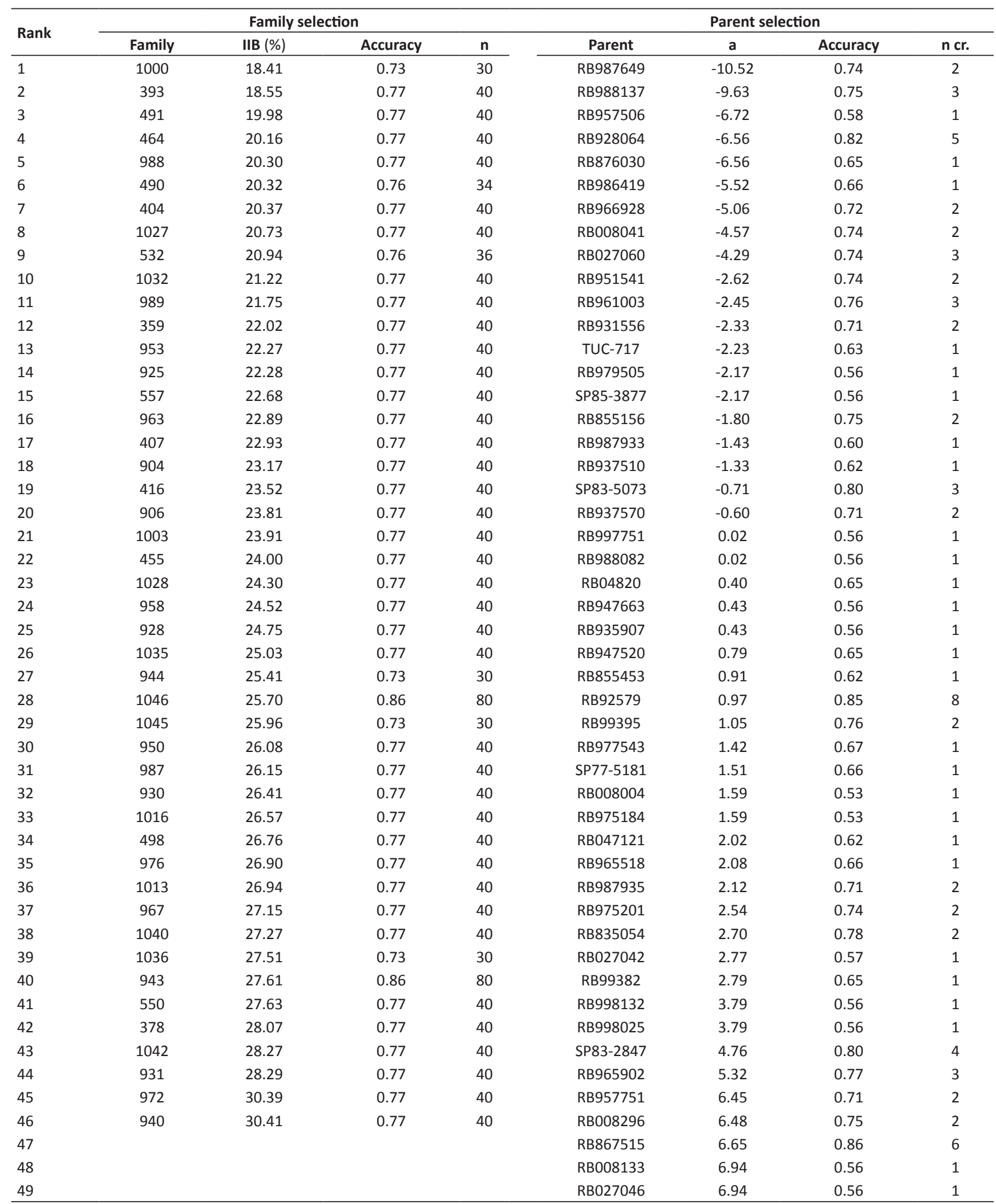

* $\mathrm{a}=$ additive genetic value; $\mathrm{n}=$ number of individuals assessed per family; $\mathrm{n} \mathrm{cr}$ = number of crosses involving the parent. 
significant $\left(\sigma_{d}^{2}=0.35\right)$ (Table 2). Therefore, the genetic additive effect or general combining ability (GCA) is more important for borer resistance than the dominance effect or specific combining ability (SCA), and exploitation of heterosis would not increase genetic gain (Bastos et al. 2003). White et al. (2001) also observed that the additive genetic effect is more important than the dominance effect in governing sugarcane resistance to $D$. saccharalis. However, previous studies have suggested the presence of additive and nonadditive genetic effects of sugarcane resistance to African borer (Zhou 2015, Zhou and Mokwele 2015).

The additive genetic effects of parents (a) ranged from -10.52 to 6.94 , showing the genetic variability of parents to borer resistance (Table 3). The accuracy of estimating additive effects of parents ranged from 0.53 to 0.86 (Table 3). Parents represented in only one cross showed relatively low accuracies $(<0.70)$, while the genotypes represented by two or more crosses showed accuracies higher than 0.70 . However, due to the difficulty of synchronizing the flowering of parents, this is not always possible in large sugarcane breeding programs. Therefore, for estimates to be reliable such that one can use them for parental selection, we would need to derive such estimates from parents that have been involved in at least two crosses. Nevertheless, three or four crosses per genitor would provide better estimates of their additive values and such crosses should be used when possible (Resende and Barbosa 2005). Considering only the parents represented in at least two crosses, the predicted genetic gain is $-20.5 \%$, which indicates that selecting the most resistance parents for further crosses may enhance the borer resistance of the sugarcane population in breeding programs. The genotypes RB987649, RB988137, RB928064, and RB966928 were the most promising parents for borer resistance.

\section{Selection of sugarcane for resistance to borer at the first clonal stage (T2)}

The genetic variance among clones within families was significant $\left(\sigma_{c / f}^{2}=9.13\right)(P<0.001)$ (Table 2$)$. The genotypic values for clone means $(u+g)$ ranged from 6.63 to $17.57 \%$ of bored internodes, indicating that differences exist among clones for borer resistance (Table 4). Heritability at the clone mean level was moderate $\left(h^{2}=0.61\right)$, suggesting a high possibility of obtaining satisfactory genetic gains. The predicted genetic gain from selecting the 12 most resistant clones (selection intensity 20\%) is $-28.96 \%$.

Our study agrees with the literature, which states that family selection, when followed by individual clone selection, is superior regarding genetic gain than either family or
Table 4. Genotypic values (BLUP) for infestation index by borer - IIB (\%) at T2 stage and family resistance category at T1 stage.

\begin{tabular}{|c|c|c|c|c|}
\hline Rank & Family category at the T1 stage & Family & Clone & IIB (\%) \\
\hline 1 & res & 393 & 56 & 6.63 \\
\hline 2 & res & 393 & 61 & 7.54 \\
\hline 3 & res & 393 & 47 & 7.89 \\
\hline 4 & res & 393 & 54 & 7.96 \\
\hline 5 & sus & 972 & 34 & 8.08 \\
\hline 6 & res & 393 & 65 & 8.23 \\
\hline 7 & res & 393 & 45 & 8.31 \\
\hline 8 & res & 393 & 53 & 8.32 \\
\hline 9 & sus & 940 & 8 & 8.50 \\
\hline 10 & sus & 972 & 33 & 8.72 \\
\hline 11 & sus & 931 & 24 & 8.78 \\
\hline 12 & sus & 931 & 28 & 8.82 \\
\hline 13 & res & 393 & 59 & 8.97 \\
\hline 14 & sus & 931 & 13 & 9.26 \\
\hline 15 & sus & 972 & 35 & 9.54 \\
\hline 16 & res & 393 & 68 & 9.79 \\
\hline 17 & res & 393 & 52 & 9.97 \\
\hline 18 & sus & 940 & 26 & 10.02 \\
\hline 19 & sus & 940 & 25 & 10.08 \\
\hline 20 & res & 393 & 46 & 10.10 \\
\hline 21 & res & 393 & 62 & 10.21 \\
\hline 22 & res & 393 & 48 & 10.26 \\
\hline 23 & sus & 972 & 31 & 10.43 \\
\hline 24 & sus & 940 & 20 & 10.71 \\
\hline 25 & res & 491 & 50 & 10.94 \\
\hline 26 & res & 393 & 60 & 11.09 \\
\hline 27 & sus & 931 & 16 & 11.11 \\
\hline 28 & res & 1000 & 7 & 11.16 \\
\hline 29 & res & 1000 & 4 & 11.17 \\
\hline 30 & res & 393 & 66 & 11.21 \\
\hline 31 & sus & 940 & 18 & 11.29 \\
\hline 32 & sus & 931 & 29 & 11.31 \\
\hline 33 & sus & 940 & 11 & 11.33 \\
\hline 34 & sus & 940 & 21 & 11.52 \\
\hline 35 & sus & 931 & 27 & 11.58 \\
\hline 36 & res & 393 & 51 & 11.59 \\
\hline 37 & sus & 931 & 15 & 11.59 \\
\hline 38 & res & 491 & 57 & 11.62 \\
\hline 39 & res & 393 & 44 & 11.81 \\
\hline 40 & res & 491 & 64 & 12.04 \\
\hline 41 & res & 1000 & 5 & 12.09 \\
\hline 42 & sus & 972 & 41 & 12.15 \\
\hline 43 & sus & 931 & 17 & 12.35 \\
\hline 44 & res & 1000 & 1 & 12.55 \\
\hline 45 & res & 393 & 67 & 12.67 \\
\hline 46 & res & 393 & 55 & 12.92 \\
\hline 47 & res & 491 & 49 & 12.95 \\
\hline 48 & res & 491 & 63 & 13.30 \\
\hline 49 & sus & 972 & 42 & 13.31 \\
\hline 50 & res & 1000 & 3 & 13.43 \\
\hline 51 & sus & 940 & 19 & 13.49 \\
\hline 52 & sus & 931 & 14 & 13.64 \\
\hline 53 & sus & 972 & 30 & 13.91 \\
\hline 54 & res & 1000 & 2 & 14.11 \\
\hline 55 & res & 1000 & 6 & 14.37 \\
\hline 56 & sus & 931 & 12 & 14.43 \\
\hline 57 & sus & 972 & 40 & 14.54 \\
\hline 58 & sus & 940 & 9 & 14.73 \\
\hline 59 & sus & 940 & 22 & 15.05 \\
\hline 60 & sus & 972 & 43 & 16.17 \\
\hline 61 & sus & 972 & 39 & 16.41 \\
\hline 62 & sus & 940 & 10 & 17.05 \\
\hline 63 & sus & 940 & 23 & 17.19 \\
\hline 64 & res & 491 & 58 & 17.57 \\
\hline
\end{tabular}

* The codes res and sus mean that the clone was selected from a resistant or susceptible family in the T1 stage, respectively. 
individual clone selection alone, as selection within families with higher genotypic values can increase the probability of selecting superior clones (Barbosa et al. 2005, Brasileiro et al. 2016). In our study, nearly $60 \%$ of the selected clones came from the more resistant families selected in the seedling stage. In addition, the most resistant clones $(56,61$, 47, and 54) were derived from a resistant family, RB876030 $\times$ RB928064. Indeed, the high variance within families for borer resistance enabled a high frequency of resistant clones within families with lower means and high variance, which reinforces the idea that family selection at the T1 stage must be followed by clone selection at the T2 stage.

Sugarcane resistance to borer is the sum of several genes that confers the trait of some resistance. Several resistance traits in Brazilian sugarcane genotypes, such as antibiosis and antixenosis, have been reported (Dinardo-Miranda et al. 2012, Tomaz et al. 2017, Pimentel et al. 2017). Our results also show the high genetic variability for borer resistance in Brazilian sugarcane populations. This genetic variability should be exploited by the breeder to increase the resistance of varieties. Overall, our data shows that sugarcane borer resistance has a very complex genetic control, with high genetic variance both among and within families.

\section{CONCLUSION}

- In the T1 population, heritability at the family mean level was higher than individual heritability, so family selection is more effective than individual selection at the T1 stage.

- The families RB027060 × RB957506, RB876030 × RB928064, RB988137 × RB951541, RB966928 × RB855156, and RB987649 $\times$ RB867515 were the families most resistant to borer.

- The additive genetic effect was more important for borer resistance than non-additive effects. Therefore, parents may be selected through their additive effects for borer resistance.

- The genotypes RB987649, RB988137, RB928064, and RB966928 were the most promising parents for borer resistance (considering accuracy higher than 0.70).

- In the T2 stage, heritability at the clone mean level was moderate $\left(h^{2}=0.61\right)$, indicating the possibility of selecting clones for borer resistance.

- Genotypic variance among clones within families was significant, so selection of families at the T1 stage must be followed by clone selection at the T2 stage to identify superior clones within the selected families.

- The most resistant clones $(56,61,47$, and 54) were derived from a resistant family, RB876030 $\times$ RB928064. We can conclude that family experiments enable selection of more promising families and parents for borer resistance.

\section{ACKNOWLEDGEMENTS}

We thank the technical assistance provided by the Inter-University Network for the Development Sugarcane Industry in Brazil (RIDESA). The financial support provided by the National Council of Scientific and Technological Development (CNPq), CAPES Foundation (Brazilian Ministry of Education), the Minas Gerais State Foundation for Research Aid (FAPEMIG), and the RIDESA-UFV Sugarcane Breeding Program was greatly appreciated and acknowledged here.

\section{REFERENCES}

Barbosa MH, Resende MD, Peternelli LA, Bressiani JA, Silveira LC, Silva $\mathrm{FL}$ and Figueiredo IC (2004) Use of REML/BLUP for the selection of sugarcane families specialized in biomass production. Crop Breeding and Applied Biotechnology 4: 218-226.

Barbosa MH, Resende MD, Bressiani JA, Silveira LC and Peternelli LA (2005) Selection of sugarcane families and parents by Reml/Blup. Crop Breeding and Applied Biotechnology 5: 443-450.

Barbosa MH, Resende MD, Dias LAS, Barbosa GV, Oliveira RA, Peternelli LA and Daros E (2012) Genetic improvement of sugar cane for bioenergy: the Brazilian experience in network research with RIDESA. Crop
Breeding and Applied Biotechnology 12: 87-98.

Bastos IT, Barbosa MHP, Cruz CD, Burnquist WL, Bressiani JA and Silva FD (2003) Análise dialélica em clones de cana-de-açúcar. Bragantia 62: 199-206.

Brasileiro BP, Mendes TOP, Peternelli LA, Silveira LCI, Resende MDV and Barbosa MHP (2016) Simulated individual best linear unbiased prediction versus mass selection in sugarcane families. Crop Science 56: 570-575.

Cristofoletti PT, Kemper EL, Capella AN, Carmago SR, Cazoto JL, Ferrari F, Galvan TL, Gauer L, Monge GA, Nishikawa MA and Santos NZ (2018) Development of transgenic sugarcane resistant to sugarcane 


\section{AC Tomaz et al.}

borer. Tropical Plant Biology 11: 17-30.

Dinardo-Miranda LL, Anjos IAD, Costa VPD and Fracasso JV (2012) Resistance of sugar cane cultivars to Diatraea saccharalis. Pesquisa Agropecuária Brasileira 47: 1-7.

Girón-Pérez K, Oliveira AL, Teixeira AF, Guedes RNC and Pereira EJG (2014) Susceptibility of Brazilian populations of Diatraea saccharalis to Cry $1 \mathrm{Ab}$ and response to selection for resistance. Crop Protection 62: 124-128.

Kimbeng CA and Cox MC (2003) Early generation selection of sugarcane families and clones in Australia: a review. Journal American Society of Sugarcane Technologists 23: 20-39.

Peternelli LA, Moreira EFA, Nascimento M and Cruz CD (2017) Artificial neural networks and linear discriminant analysis in early selection among sugarcane families. Crop Breeding and Applied Biotechnology 17: 299-305.

Pimentel GV, Tomaz AC, Brasileiro BP, Peternelli LA and Barbosa MHP (2017) Oviposition preference and larval performance of sugarcane borer in eight sugarcane genotypes. Ciência e Agrotecnologia 41: 439-446.

Resende MDV (2016) Software Selegen-REML/BLUP: a useful tool for plant breeding. Crop Breeding and Applied Biotechnology 16: 330 -339.

Resende MDV and Barbosa (2005) Melhoramento genético de plantas de propagação assexuada. Embrapa Florestas, Colombo, 130p.

Santana PND, Reis AJDS and Chaves LJ (2017) Combining ability of sugarcane genotypes based on the selection rates of single cross families. Crop Breeding and Applied Biotechnology 17: 47-53.

Tomaz AC, Coutinho AE, Soares BO, Peternelli LA, Pereira EJG and Barbosa
MHP (2017) Assessing resistance of sugarcane varieties to sugar cane borer Diatraea saccharalis Fab. (Lepidoptera: Crambidae). Bulletin of Entomological Research 108: 547-555.

White WH, Legendre BL, Miller JD and Dunckelman JW (1993) Registration of five sugarcane borer resistant sugarcane germplasm clones. Crop Science 33: 348-349.

White WH, Burner DM, Legendre BL and Miller JD (1998) Registration of 12 sugarcane germplasm clones resistant to sugarcane borer: HoCP 92-678, НоСР 93-775, НоСР 93-776, US 93-15 to US 93-17, and US $96-1$ to US $96-6$. Crop Science 38: 1726-1727.

White WH, Miller JD, Milligan SB, Burner DM and Legendre BL (2001) Inheritance of sugarcane borer resistance in sugarcane derived from two measures of insect damage. Crop Science 41: 1706-1710.

White WH, Hale AL, Veremis JC, Tew TL and Richard EP (2011) Registration of two sugarcane germplasm clones with antibiosis to the sugarcane borer (Lepidoptera: Crambidae). Journal of Plant Registration 5: 248-253.

Zhou M and Mokwele A (2016) Family versus individual plant selection for stem borer (Eldana saccharina) resistance in early stages of sugarcane breeding in South Africa. South African Journal of Plant and Soil 33: 89-96.

Zhou M (2015) Selection for Eldana saccharina borer resistance in early stages of sugarcane breeding in South Africa. American Journal of Plant Sciences 6: 2168-2176.

Zhou M (2016) Family selection as a strategy for stem borer (Eldana saccharina Lepidoptera: Pyralidae) resistance breeding in South Africa. American Journal of Plant Sciences 7: 2006-2019. 